\title{
IMPACT OF INSTITUTIONAL SUPPORT FOR THE DEVELOPMENT OF BULGARIAN ORGANIC PRODUCTION
}

\author{
R. Otouzbirov*, A. Petkova, K. Stankov, M. Ignatov \\ Faculty of Economics, Trakia University, Stara Zagora, Bulgaria
}

\begin{abstract}
Over the last decade Bulgarian organic farming has been growing at an increasing rate. Over the same period, the demand for quality food products on national and international markets also increased. Institutional support for the sector is important for the development of sustainable environment for the production and marketing of organic products.

The goal of the present study is to analyze the impact of institutional support on the development of Bulgarian organic production.

To achieve this goal, the following tasks need to be addressed: Assess the state of public support for the sector; to analyze the production and marketing of Bulgarian organic products.
\end{abstract}

Key words: agriculture, sustainability, CAP

\section{INTRODUCTION}

Organic production is one of the most dynamically developing sectors of agriculture in recent years, both in the EU-28 and in our country. Organic agriculture is supported under the CAP pillar 2, which includes rural support measures. According to Mitova (2018), in about half of the EU-28 countries, areas in the transition to organic farming (PA) in the last three years have been between 10 and $30 \%$ of all PA areas. In Bulgaria, they are between 70 and $82 \%$ (the highest percentage in the EU28). The share of areas in transition to $\mathrm{BZ}$ is an indicator of the growth potential of the sector over the next few years and a type of guarantee for a significant increase of organic products of Bulgarian origin on the domestic and international markets.

The organic products market in Bulgaria is significantly ahead of production. The majority (more than 80\%) of organic foods in Bulgaria are exported - mainly to the European market mostly in Germany, the Netherlands, France, Italy. There are also exports to the USA, Japan, Korea and Canada. Bulgaria is one of the

\footnotetext{
*Correspondence to: Roumen Otouzbirov, Faculty of Economics, Trakia University, Stara Zagora 6000,Bulgaria,otuzbirov_r@abv.bg
}

largest exporters of wild dried wild berries and herbs. Frozen fruits - strawberries, raspberries and blueberries, organic honey, essential oils of rose, lavender, mint, cheese, yellow cheese and jams are exported and found very well on the international market (Kostadinova, 2012). Bulgarian bioproducts are competitive in foreign markets, as they are not inferior in quality, have lower costs and are offered at lower prices, meet all requirements and standards and are unique (Krasteva, 2014).

Organic agriculture in Bulgaria is in the initial stages of its development, but the trends are up and it is developing at a rapid pace. For the period 2006-2016, the number of organic operators and areas in organic production has increased more than 10 times, the number of cattle and bee families has increased 5 times, the number of sheep has been increased by 10 times and the number of goats has been increased more than 25 times.

With the launch of the new Rural Development Program (RDP) for the period 2014-2020, the expectations for organic farming are increasing as euro-funding for organic production has increased 5-fold (33 million were planned in the previous RDP). EUR 152 million is invested in the new one). Funding for organic 
livestock is also foreseen for the first time, including measures such as pastoralism (seasonal grazing), conservation of endangered local breeds and other activities.

\section{LEVEL OF INSTITUTIONAL SUPPORT FOR BULGARIAN ORGANIC FARMING}

In accordance with the provisions of the Regulation of the European Parliament and of the Council on support for rural development by the European Agricultural Fund for Rural Development for the period 2014-2020, Bulgaria has developed a separate measure: 11 "Organic agriculture" under the new program period of the Rural Development Program
2014-2020 Two measures are being implemented under this measure: Sub-measure 11.1- Payments for conversion to organic farming per hectare and Sub-measure 11.2 Payments for maintenance of bio-diversity during farming per hectare.

The financial value of the institutional support for organic agriculture in Bulgaria is presented in Ordinance No. 4 of MAF (2015) - Table 1. The level of support during the transition period is higher than the post-transition period due to the increased costs of producers in transforming their activities from traditional to compliant organic production.

Table 1. Annual amount of payments for organic farming.

\begin{tabular}{|l|l|l|}
\hline Activities & $\begin{array}{l}\text { During the } \\
\text { transition } \\
\text { period }\end{array}$ & $\begin{array}{l}\text { Undergone a } \\
\text { transitional } \\
\text { period }\end{array}$ \\
\hline 1. Arable crops, incl. Feed & 284 euro/ha & 168 euro/ha \\
\hline 2. Permanent grassland & $128 \mathrm{euro} / \mathrm{ha}$ & $112 \mathrm{euro} / \mathrm{ha}$ \\
\hline 3. Perennials, vineyards, oleaginous Rose & $736 \mathrm{euro} / \mathrm{ha}$ & $557 \mathrm{eur} / \mathrm{ha}$ \\
\hline 4. Aromatic and medicinal plants & $515 \mathrm{euro} / \mathrm{ha}$ & $405 \mathrm{euro} / \mathrm{ha}$ \\
\hline 5. Vegetable crops & $575 \mathrm{euro} / \mathrm{ha}$ & $399 \mathrm{eur} / \mathrm{ha}$ \\
\hline 6. For Bee Family & $35 \mathrm{euro} / \mathrm{ha}$ & 25 euro/ha \\
\hline 7. Cattle and buffalo reared for milk & $230 \mathrm{euro} / \mathrm{ha}$ & 77 euro/ha \\
\hline 8. Cattle and buffalo reared for meat & $160 \mathrm{euro} / \mathrm{ha}$ & $63 \mathrm{euro} / \mathrm{ha}$ \\
\hline $\begin{array}{l}\text { 9. Small ruminants (ovine and caprine animals) for milk and } \\
\text { meat }\end{array}$ & $122 \mathrm{euro} / \mathrm{ha}$ & $90 \mathrm{euro} / \mathrm{ha}$ \\
\hline
\end{tabular}

Source: Ordinance No. 4 of the 24.02.2015 for the implementation of Measure 11 "Organic farming" of the RDP for the period 2014-2020 years

In the first year of operation of the Ordinance, 2,116 applications for support were approved, with payments of BGN 28119231 being paid, $75 \%$ of which were financed by EU funds and $25 \%$ from the national budget. One applicant may be supported at the same time for carrying out activities in more than one direction during the period of application of the organic farming measure, the maximum amount of this support being for annual crops of EUR 600 / ha; for specialized perennial crops - EUR 900 / ha, and for other land uses - EUR 450 / ha. The latter category most often includes livestock producers combining support for pasture maintenance in the control system and livestock units reared using the appropriate pasture. This dualistic support scheme allows producers to reach the higher levels of institutional support required to meet the increased costs of operating a business that meets the requirements of Regulation No. 1 (2013). The biological activities are carried out for a period of 5 years, with area payments covering the additional costs and income foregone resulting from the biological management.

According to data from the MAF Agricultural Report (2017) at the end of 2016, the total number of biological operators registered with the Ministry of Agriculture and Food are 7262 - by 1,089 more than a year earlier and more than 200 in more for the period of EU's CAP financing. Of these, 6,961 are producers, 3 are aquaculture producers, 177 organic processors and 121 traders (importers, exporters, wholesalers and retailers). In 2016, the number of operators in the organic production control system represented $7.4 \%$ of the total number of registered farmers under Ordinance No. 3 of 1999 on the establishment and maintenance of a register of farmers.

The use of financial support under measure 11 has had a favorable effect on the development of the production capacity of organic livestock in Bulgaria. Organic or organic livestock breeding means breeding animals adapted to local conditions, using breeding methods that 
are close to the natural way of life, which reduce stress and ensure good health. Animals are fed with organic fodder, the use of growth regulators is prohibited and the use of antibiotics is limited to a minimum. The relationship between the number of animals and the area under cultivation is also closely monitored. It is obligatory to provide sufficient space for the manifestation of their natural behavior such as walking and grazing in the open air, etc. (Ordinance No. 1 of the MAF of 07.02.2017).
The state of organic farming in Bulgaria has changed dynamically over the past programming period of the EU CAP. Between 2011 and 2016, both the number of organically farmed animals in the country (Table 2) and the areas registered in the control system increased sharply (Table 3). The most pronounced growth is in bee families, where more than $30 \%$ are organically reared at the end of the period.

Table 2. Number of animals reared organically

\begin{tabular}{|l|l|l|l|l|l|l|}
\hline & 2011 & 2012 & 2013 & 2014 & 2015 & 2016 \\
\hline Bovine animals & 976 & 1173 & 1311 & 1622 & 4209 & 9718 \\
\hline Sheep & 6648 & 9175 & 7894 & 9029 & 18792 & 26809 \\
\hline Goats & 3397 & 2831 & 3235 & 4142 & 5381 & 8242 \\
\hline Bee colonies & 58855 & 85346 & 117360 & 106676 & 178331 & 236462 \\
\hline
\end{tabular}

Source: Eurostat

When examining the registered operators in the control system, it is noticed that the registered producers of organic animals are also registered as pasture farmers. This requirement, which underlies both regulations, allows us to analyze the correlation between pastures in the control system and livestock units.

The institutional support for organic animal husbandry in Bulgaria is embodied in Regulation No. 4 of February 24, 2015, developed by the Ministry of Agriculture and Food on the implementation of Measure 11 "Organic Agriculture" of the RDP for the period 2014-2020. It describes the requirements to bio-producers and the form and amount of support for individual crops and farm animals. The area under the control system shows significant growth, which is not inferior in its growth rate to the number of organically reared animals (Table 3). This is due to the requirements laid down in Ordinance No. 1 and Ordinance No. 4 of the MAF for the presence of a minimum volume of pasture land for the organic farming of farm animals. In calculating the amount of institutional support for organic livestock, the equation to Animal Unit shall be used according to the following rules: buffalo and one bovine animal over two years equals one LU; cattle or buffalo from 6 months to 2 years equals $0.6 \mathrm{LU}$; cattle or buffalo up to 6 months equals $0.4 \mathrm{LU}$; one sheep or one goat equals $0.15 \mathrm{LU}$. The amount of support is formed at the equality of $1 \mathrm{LU}=1$ ha. pastures in the control system.

Based on our own calculations and analysis of equated animal units available as of 2016, farmed in the amount of more than $8400 \mathrm{LU}$ and permanent meadows and pastures with a total area of 38736 ha. we can conclude that the development of organic pastures in Bulgaria allows to maintain the rate of development of organic animal husbandry in the country, with the free support base in the sector by these criteria being more than $75 \%$. The exclusion of organic beekeeping from the calculations and analysis made is based on the presence of significant areas with wild crops in the control system, which are more often used by the producers of organic bee products in the country.

Presented in Table 3 results of the area dynamics in the control system complements the results reported by the analysis for the development of organic livestock in the country. The rapid growth trends in the control system are extremely interesting and require in-depth analysis that goes beyond the objectives set out in this report. However, it should be noted that the largest share of pastures is in the total area of the control system, and they also show the fastest growth, which is an additional incentive for the development of organic livestock, creating a base for it. 
Table 3. Areas in the control system (organic farming)

\begin{tabular}{|l|l|l|l|l|l|l|}
\hline Crop Group (ha) & 2011 & 2012 & 2013 & 2014 & 2015 & 2016 \\
\hline Cereals, incl. grain crops Rice & 6521 & 7532 & 7669 & 12061 & 22191 & 30940 \\
\hline Technical crops-General & 5846 & 7909 & 10924 & 12878 & 20873 & 30512 \\
\hline $\begin{array}{l}\text { Crops for green/forage crops from } \\
\text { arable land }\end{array}$ & 995 & 2044 & 2881 & 5215 & 8330 & 14911 \\
\hline Perennials & 6442 & 10959 & 16885 & 18213 & 25946 & 33174 \\
\hline Permanent meadows and pastures & 4491 & 7957 & 15476 & 21831 & 31796 & 38736 \\
\hline Fallow & 1513 & 2315 & 2905 & 2205 & 6209 & 8075 \\
\hline Total areas in the control system & 26622 & 40379 & 58107 & 74351 & 118571 & 156348 \\
\hline Wild-growing crops & 543655 & 472700 & 678025 & 694251 & 901617 & 307995 \\
\hline
\end{tabular}

Source: MAF Agrotics

The budget from the public funds adopted under the RDP 2014 - 2020 (EAFRD + NF) was 151593439 euro, and at the end of 2016 $100 \%$ implementation was reported on the basis of paid applications and commitments to the overall budget of the measure.

For the second consecutive year, the State Fund for Agriculture (2018) will not make new commitments for financing organic farming due to the exhausted financial resources under Measure 11. Increase in crops and livestock production will also not be supported. At this stage, bio-producers can receive financial support for investment sub-measures 4.1. "Investments in agricultural holdings" and 4.2. "Investment in processing / marketing of agricultural products"

Only $3.2 \%$ of the agricultural land, or 161 thousand hectares, in Bulgaria is certified for organic farming, Eurostat 2016 data show. Thus, our country lags behind the average European level, where $6.7 \%$ of the agricultural area is used for organic farming.

\section{CONCLUSION}

Bulgaria has favorable opportunities for the development of organic agriculture, the main ones being summarized as follows: appropriate soil and climatic conditions; existing set of knowledge and skills; a functioning system of scientific, educational and consulting units; good image of Bulgarian agricultural products (food) on the domestic and foreign markets; availability of production capacity in the food industry; growing demand for organic products.

In order to realize these opportunities in a timely manner, it is necessary to implement appropriate measures, some of which may be: - reducing the value added tax of organic products;
- stricter controls and penalties for unfair competition from eco-labeled products;

- support for promotional activities and other marketing initiatives for the distribution of bioproducts;

- providing information and expanding the knowledge of producers and consumers about organic food, etc.

Organic farming has a perspective - it directly contributes to the conservation of the environment and ecosystems, the restoration of natural resources, and the development of rural areas. It can stabilize the income of Bulgarian farmers through the ability to market healthy food products to new markets. In this way, the competitive advantage of the natural and climatic conditions in our country and the support from the European funds will be used to the maximum benefit from the agricultural producers.

As a result of the analysis we have come to the conclusion that the level of institutional support allows the organic agriculture in the country to undergo significant development and public support has a positive role in this process. The available pasture base in the control system has not yet been fully utilized, which will further have a positive impact on the development of the sector.

The European market for organic products has grown about 5 times since 2000, while the area under organic farming in the EU has increased about 2 times over the period. The gap between production and demand for organic products in the EU is covered by imports. As a consequence, missed opportunities for $\mathrm{EU}$ producers arise, the bio-products market is narrowed, and environmental benefits diminished. It is necessary to provide funds for the next programming period to satisfy all the claimed areas and animals in the sector, which 
will contribute to the sustainable development of organic agriculture in Bulgaria.

\section{REFERENCES}

1. MAF Agricultural Report, 2011-2017

2. SFA-RA, 2018, Updated indicative timetable for receipt of applications for support under the Rural Development Program 2014-2020, during the calendar year 2018.

3. State Agricultural Fund, 2014, Rural Development Program 2014-2020.

4. Ordinance No. 4 of February 24, 2015, on the implementation of Measure 11 "Organic Agriculture" of the RDP for the period 2014-2020.

5. Ordinance No 1 of 7 February 2013 On the application of the rules on organic production of plants, animals and aquaculture, plant, animal products, aquaculture and food products, their labeling and control of production and labeling (in force since 19.02. 2013)
OTOUZBIROV R., et al.

6. Kostadinova, P., Vl.Popov, 2012, Basic Principles and Methods of Organic Farming, Sp. New Knowledge, year 1, issue 3 , ed. VUARR, Plovdiv, p.58

7. Krasteva, Il., 2014, State and tendencies for the development of organic production in Bulgaria for the period 2006-2012, Collection of reports from the Jubilee Conference "The National Agrarian Sector an Element of the European Agricultural Regions in the Europe 2020 Strategy", Aizd. Tsenov Svishtov, p.179

8. Mitova, D., 2014, Organic production - a priority of Bulgarian agriculture in the new programming period 2014-2020, Journal of Economics and Management of Agriculture, Issue 3, IAI, Sofia, pp.4-7

9. Mitova, D., 2018, Organic agriculture in Bulgaria in the period 2007-2016, Sectoral analyzes in agriculture, Project HTAI №144.2, SASAI, Sofia, p.53-60

10.Eurostat.

11.UN Comtrade. 